\title{
Potentials for innovative restructuring of industry in Northwestern Russia
}

\author{
MARKKU TYKKYLÄINEN AND HEIKKI JUSSILA
}

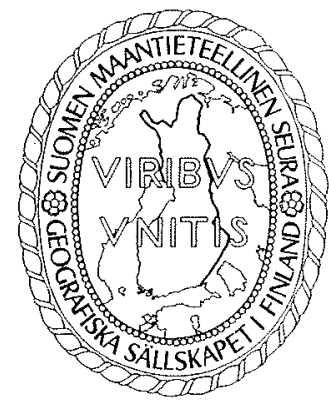

Tykkyläinen, Markku \& Heikki Jussila (1998). Potentials for innovative restructuring of industry in Northwestern Russia, Fennia 176:1, pp. 223-245. Helsinki. ISSN 0015-0010.

This paper examines the innovative restructuring of industry in Northwestern Russia, an area that includes St. Petersburg and its hinterlands and extends to the Barents Sea and the Ural Mountains. Profound restructuring of resource-based industries is taking place there although at a slow rate. The paper elaborates upon the reasons for the slow recovery of industry and searches for ways to explain the innovative restructuring of the Northwestern Russian economy. This research explicates that restructuring is partly regulated by inherited institutional and organizational structures and restricted by the flaws of the service sector. The importance of political choices in development is also discussed. The region's role in the division of labor within Europe is considered and viewed as an incentive for restructuring. In concluding, the elements of theories of innovative restructuring of industry and selective spatial modernization are presented.

Markku Tykkyläinen, Department of Geography, University of Joensuu, P.O. Box 111, FIN-80101 Joensuu, Finland. Heikki Jussila, Thule Institute, University of Oulu, P.O. Box 400, FIN-90571 Oulu, Finland. MS. received $30^{\text {th }}$ January, 1997 (revised $15^{\text {th }}$ January, 1998).

\section{Restructuring and innovative behavior}

Economic development and economic growth are linked to a society's capability for using knowledge as a tool. Economic restructuring is innovative when it introduces novel, useful and desired production methods and products to replace old ones (GartiserSchneider 1997). In this paper, this micro level approach of innovation is adopted in order to assess the modernization of Northwestern Russian industry. On the other hand, social innovations (such as the market economy) at a macro level are preconditions for successful industrial restructuring. Both viewpoints are attempted to be intertwined, investigating the conditions of the structural transformation of the economy in particular.

There have been lively discussions on how 'structuring' takes place in a broader sense in society (e.g. Thrift 1983; Giddens 1984; Cloke et al. 1991: 93-131), and it can be argued that the restructuring process is directed by human practices and existing social formations. This fact, together with recent empirical ob- servations in Russia, led to the idea of taking a closer look at the significance of past institutional structures for explaining the current transformation. There is no reason to describe the former system in-depth, only to attempt to explain the influences of the main impacts of the former system on the current transformation.

The former Soviet Union had a commanding, multi-tier system for economic development. The development of innovations was regulated within that system, and from the Western standpoint, some sectors such as space research and military production were accentuated at the expense of consumer goods (van Zon 1996: 133). According to Linz (1992: 73), the Soviet incentive system failed to compensate for the risk of innovation and hence represented a major barrier to the introduction of new technology. As profit indicators did not influence applied research and development and there was no 'civil scientific society' to promote innovation diffusion (Dyker 1994: 76-78; Bater 1996: 70-71), it is reasonable to argue that innovation diffusion did not exist in the former Soviet economy in the 
same sense as in market economies. Innovative behavior, assumed to seek highest returns, was not a driving force in the economy.

In a market economy, innovations are developed by companies in order to foster more profitable production and by individuals for selfish motives. This behavior is a prime inducer in the innovative restructuring of industry. The traditional route towards innovations can be reinforced through research organizations and universities, which are especially designed to disseminate the development of new knowledge and technology (Nijkamp et al. 1994). This strategy has been implemented in the United States, within the European Union and in the Pacific Rim (e.g. Aydalot \& Keeble 1989; Smilor et al. 1988; Haug 1991; Castells 1992), where it has also been found to be a viable method for achieving progress in less developed and problematical regions. This discourse has usually proceeded from the notion of creating innovative environments for growth (van Doren 1995; Malmberg et al. 1996). Recent research. has emphasized the creation of knowledgebased and innovative culture as a condition for economic development, and such culture should become thoroughly embedded into the entire society (Bellandi 1997; Wilhelm 1997). The economic growth in Southeast Asia, the most recent example of profound economic transformation, continued until the latter 1990 s, and it was accomplished by creating a successful combination of production factors and progressive environments for growth. Since the significance of the state in regulating the conditions of production has been considerable in Asia (Castells 1992; Korhonen 1994), development may be said to have taken place intentionally, in the form of political objectives and programs in each country. Social capital, capable of producing innovations, was thus created by public authorities, enterprises and individuals in concert.

The role of innovations and associated market-supporting institutions in the case of the transitional situation in Russia is a 'fuzzy' one. One reason for this is the immature nature of the new social order in Russia. In light of the former socialist tradition and the feudal tradition that preceded it, even the market economy as such is an innovation in Russia (Rakitov 1993; Marianovski 1997). Such basic concepts as profit, the market and productivity, for instance, need to be properly understood as preconditions for innovative behavior in order to achieve an advanced economy. In a broader setting, these preconditions can be reduced to the issue of society's capabilities to accept new market-led ideas and developments. A transition of this kind very often presupposes fundamental changes in values, norms and rules embodied in the institutions of society and in the national regime and the ruling elite. Korhonen (1994: 6, 14-15) exemplifies this change by highlighting the transition in Japan and Southeast Asia from the old aristocratic, military ideology towards economism as a leading national ideology since the Second World War. This institutionalist allegory may help in understanding the profundity of the changes expected in Russia.

\section{Research questions and methods}

Although the majority of Russians voted for reform in principle in 1993 and 1995, it is unclear how capable they are of achieving modernization in practice. Institutional, economic and organizational structures from the socialist period may effectively hinder development. The following questions have been put forward: What are the mechanisms for the innovative restructuring of industry in Northwestern Russia, and what kinds of elements would such a conceptualization consist of? What are the importances of various inherited structures and policy actions in restructuring? The following question arose and became central to this investigation after the initial visits to Russia: What are the experiences of restructuring from the standpoints of foreign companies in Northwestern Russia and how can the slow progress in Northwestern Russian industrial modernization be explained? Finally the paper attempted to answer the question: What are the central concepts in explaining the spatial economic restructuring of Northwestern Russia?

The above questions will be examined here in order to formulate new theoretical interpretations of economic development and to elaborate upon the economic potential of the Northwestern hinterlands of Russia, examining it from the standpoint of the European division of labor. The empirical observations presented in this paper are based mainly on interviews conducted in Russia by the authors. Research was derived from the ground- 
ed theory methods, and theoretical categories and causal mechanisms were abstracted from the empirically observable phenomena documented during a number of field trips to Northwestern Russia and by investigating multifarious secondary data. A concise structured interview survey among 72 Karelian business school students was carried out in the winter of 1997 (Tykkyläinen 1997). Furthermore, in order to improve the explanation of sluggish economic development and recovery in Russia, we applied an iterative practice in order to reconceptualize the theoretical outcomes of research, similar to Yeung's approach (1997: 66). Thus, one can follow the path of conceptualization by reading the former publications of the authors related to this topic (Tykkyläinen 1995, 1996; Jussila \& Tykkyläinen 1996; Tykkyläinen \& Jussila 1997).

\section{Search for theoretical foundations}

Alternative conceptualizations of the postsocialist transition are underway. Existing approaches range from neo-classical strands to institutional perspectives. Recent discussions tend to rely on contextual explanations rather than preserving the pure functional ones (Grabher \& Stark 1997; Hausner et al. 1997), often leading to notions of the necessity of economic reconstruction similar to that which took place in Europe, Japan and Korea (Nove 1996). Russian economic decline in particular is so severe that such ideas appear to be justifiable. From the stand point of geography, efforts to explain the deep economic decline in the northernmost parts of the country and the unevenness of modernization on various spatial scales are essential.

In attempting to find solutions to questions of why the pace of economic development varies by country and by region, it has been recognized that economic systems are socially and institutionally embedded and that economic behavior is cognitively and culturally bounded. Furthermore, there have been ideas that economic systems are structured around the formal and informal institutions, consisting of networks of affiliations and interactions (Amin \& Hausner 1997). Such an organization, if open, flexible, negotiative and having strategic and reflexive governance, could be a seedbed for the innovative restructuring of industry. It has become evident that a new economic system replacing an old one does not begin from a tabula rasa, but from various institutional legacies imposing major limitations on possible economic and political reforms. The associated dynamism of this legacy is explained by the ideas of path-dependency and path-shaping (Nielsen et al. 1995: 6-7). The idea of path-dependency rests on the idea that people in a country, and a locality, are socialized by the 'hidden curriculum' effect of institutions into accepting the values, norms and rules embodied in them. Therefore, people know, expect and anticipate that institutions can be relied upon and reckoned with (Offe 1995: 52). On the other hand, people are reproduced by institutions and institutions are reproduced by people. People are path-shaping actors in society. In certain socio-economic circumstances (such as revolutions and turmoil) there are more possibilities to create new developments and such conditions have prevailed in the former socialist countries.

Why do some regions proceed on their development path more rapidly than others? Why do some regions lag behind? The contradictions in values in the socio-economic transformation has been conceptualized by the term 'institutional lag' (Kosonen 1996). The difference in the speed of development of the formal and the informal rules generates institutional lag (Kosonen 1996: 74-81). Formal and informal rules do not correspond to each other in this situation. The emergence of an institutional lag can be interpreted as a form of passive resistance leading to the situation that the intended reforms cannot be easily carried out. It is one reason why Russia has also lagged behind in the 1990s (Kosonen 1997). When loosely applied to the current Russian socio-economic situation, this lag would perhaps arise due to several reasons: firstly, opinions about preferred economic development are diverse (Wyman 1997); secondly, there is no clear agenda for development; thirdly, individuals do not know how market economies operate; and, fourthly, there are no values and norms of market economic principles in the collective memory and institutions of society. This revelation may help to interpret the spatial implications of transition also in Northwestern Russia.

One interesting recent contribution is the idea of 'landscapes of priority' (Sjöberg 1997). It explains the spatial differentiation of economic landscapes in socialism and, further- 
more, gives insight into recent spatial transitions. This concept aims to explain why the traditional 'locational principle' approach does not disclose the observable spatial patterns of economic activities in socialism. According to the 'priority' approach, political factors, and in particular the structure of power, created the economic landscape of socialist countries. The main argument is that central planners and their superiors ensured that the most important production tasks in certain sectors were, in fact, carried out. Thus, national investment priorities determined the entire spatial system of local economies and settlements. It meant preferential resource allocations in the economy, (i.e. softer budget constraints in priority sectors), which determined spatial differentiation. It follows then that the legacy of former spatial structure is rather the legacy of political decision-making than one of rational economic planning. This reasoning certainly increases the likelihood that the mismatch of the spatial structure between the 'new' market economy and the former socialist economy is even wider than assumed, based on the former theories of spatial economic behavior. If so, economic development has to begin from scratch in the regions where the mismatch is the widest.

The western influence to speed up modernization was evident in the small East European countries, where regions close to market economies have recovered first (e.g. the Czech Republic, Estonia, the western parts of Poland). The spatial recovery of the former socialist countries has been theorized also from a geographical standpoint (e.g. Sjöberg 1997). It has been assumed that transborder transactions and investment in foci of population concentration have fostered economic growth in the border localities and large urban agglomerations. Largish cities are in an advantaged position, but large one company towns and those located in peripheral areas are most detrimentally affected by transition. Transborder economic co-operation was, and still is, lured by lower production costs. For instance, spatial developments in Poland seems to support this (Węcławowicz 1996: 162-170).

The Northwestern Russian industry faces rationalization. It seems evident that neither the modernized enterprises nor significant greenfield investment combined can even provide as many jobs as the former socialist economy did. Industrial investment will not in- crease employment as before. Clearly, from the mismatch between the current and former economic orders, job losses are not expected to be geographically coterminous with newly created jobs. As an example, a shift-share analysis (based on the regional data of 1992-93) indicates that the employment decline has been especially severe in the high-wage areas in the Far East and Far North and in military production areas (Sutherland \& Hanson 1996). In contrast, regions' capacities to earn convertible currency has had a positive effect on employment. This imbalance in the labor market leads to the migration of population and a subsistence economy as has been already seen (Klüter 1996; Varis 1996). The situation in some localities of the North is especially severe because of the long economic decline and the past investment priorities favoring the very northern reaches of the country. Nevertheless, the production decline in the Russian North has been slightly less than the average of Russia, which can be explained by the export-orientation of the raw materials and hydrocarbon industries, and moreover, by the government's protectionist policy toward this resource-rich, strategic region (Pozdniakov \& Kurnyshev 1995: 47). The above theoretical underpinnings emphasize the importance of the legacy of past structures and the recent political environment in possible explanations, leading to attempt to abstract theoretical constructs based on the circumstances of Northwestern Russia and the grounding of abstractions in concrete data.

\section{Economic base and socio-spatial conditions in Northwestern Russia}

The criteria used in defining Northwestern Russia is the principle of 'a group of regions that share a common set of socio-economic problems', which was put forward earlier to define the Russian North (Bradshaw 1995: 195). Northwestern Russia is a sparsely-populated resource periphery, but it does not possess the specific, extreme characteristics of Siberia. It is a land area which lies along the northeastern border of the EU, borders the Baltic States and is bounded by the Barents Sea in the north, the Ural Mountains in the east, and the upper course of the Volga in the south. The areas referred to as the North (Murmansk Oblast, Karelian Republic, Arkhangelsk Oblast, Vologda Oblast and the 


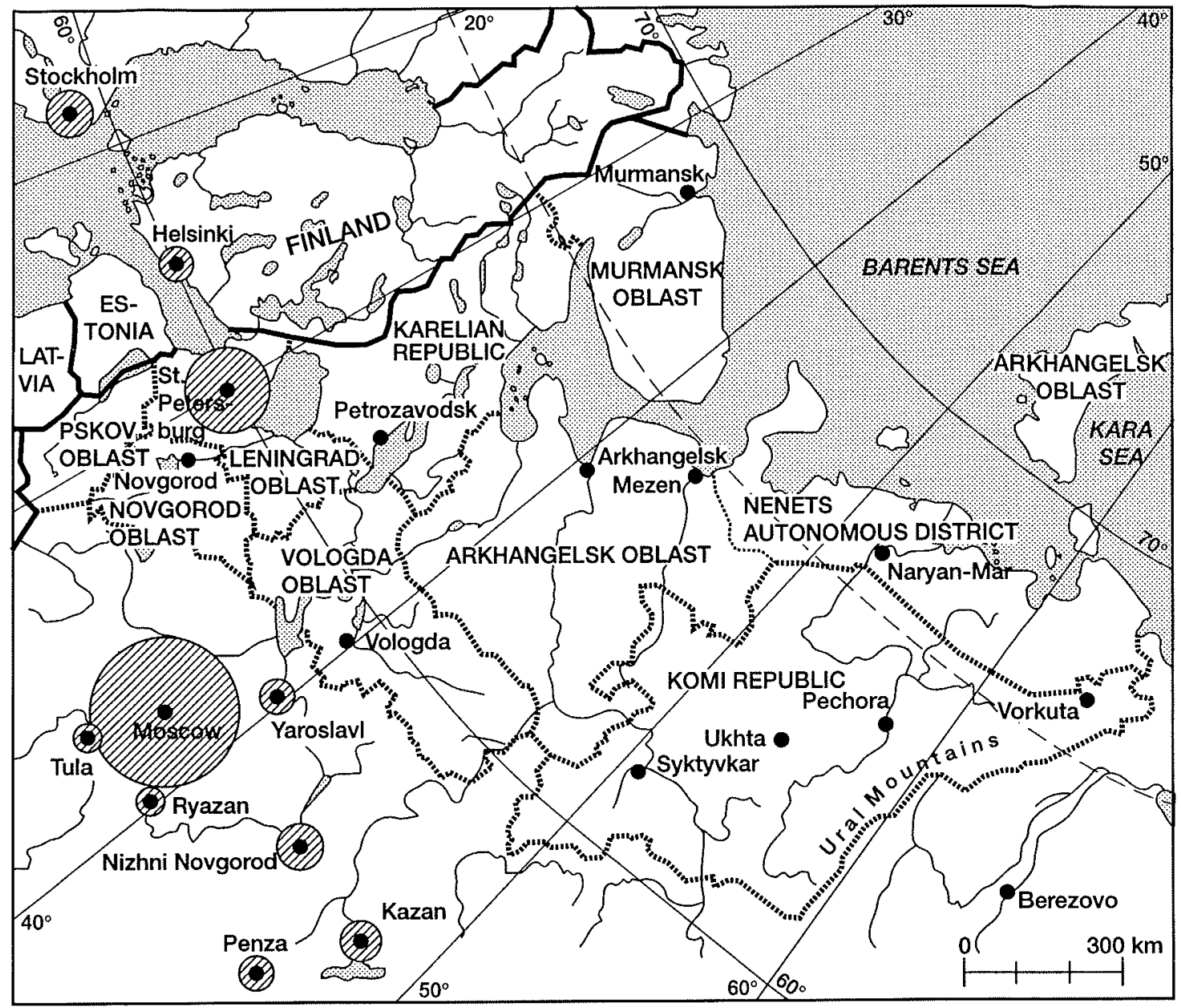

Fig. 1. The subregions of Northwestern Russia. Circles are proportional to population (cities of over 500000 inhabitants).

Komi Republic) and the Northwest (St. Petersburg, Leningrad Oblast, Novgorod Oblast and Pskov Oblast) in the Russian system of economic regions (Shaw 1995: 3; Laurila 1996: 18) together are termed Northwestern Russia. Thus, the region includes St. Petersburg as its principal city in addition to the surrounding oblasts and a vast hinterland towards the north and northeast, constituting the northwestern corner of the Russian Federation (Fig. 1). Administratively and often culturally, the northernmost oblasts and the Komi Republic are the peripheries of Moscow, from where large resource companies are managed. From the standpoint of world economy, Northwestern Russia is a hinterland of St. Petersburg rather than one of Moscow because of its large volume of resource-based products transported via the harbors of the Baltic Sea. This areal definition also reflects the opening-up of border regions which were previously focused only on Moscow (cf. Bradshaw 1997) and the rise of fresh opinions of local authorities who prefer the concept of the Northwest rather than the North (e.g. Kuzmin 1997).

The entire area of Northwestern Russia has a total population of 14 million, which is now declining (Laurila 1996: 20). Its principal city, St. Petersburg, is the largest industrial city on the shore of the Baltic Sea and, together with the Leningrad Oblast, has over 6 million in- 
Table 1. Population, income, investments and foreign trade in the five sub-regions of Northwestern Russia in 1995 (70 per cent of the total population of Northwestern Russia) (Suomen Lähialueet 3/97).

\begin{tabular}{|c|c|c|c|c|c|}
\hline $\begin{array}{l}\text { General regional } \\
\text { information: }\end{array}$ & $\begin{array}{l}\text { Arkhangelsk } \\
\text { Oblast }\end{array}$ & $\begin{array}{c}\text { Murmansk } \\
\text { Oblast }\end{array}$ & $\begin{array}{l}\text { Karelian } \\
\text { Republic }\end{array}$ & $\begin{array}{c}\text { St. } \\
\text { Petersburg }\end{array}$ & $\begin{array}{c}\text { Leningrad } \\
\text { Oblast }\end{array}$ \\
\hline Area $\left(1000 \mathrm{~km}^{2}\right)$ & 587.4 & 144.9 & 172.4 & 1.4 & 84.5 \\
\hline $\begin{array}{l}\text { Population ('000), (1992) } \\
\text { Population ('000), (1997) } \\
\text { Population change (\%), (1992-7) } \\
\text { - largest city (name) } \\
\text { - largest city (pop. ‘000) }\end{array}$ & $\begin{array}{c}1571 \\
1506 \\
-4 \\
\text { Arkhangelsk } \\
374\end{array}$ & $\begin{array}{c}1148 \\
1030 \\
-10 \\
\text { Murmansk } \\
406\end{array}$ & $\begin{array}{c}800 \\
780 \\
-2 \\
\text { Petrozavodsk } \\
380\end{array}$ & $\begin{array}{c}5004 \\
4774 \\
-5 \\
\text { St. Petersburg } \\
4276\end{array}$ & $\begin{array}{c}1674 \\
1677 \\
+0 \\
\text { Gatshina } \\
81\end{array}$ \\
\hline $\begin{array}{l}\text { Average salary/month: } \\
\text { - Feb. } 1997 \text { in USD }\end{array}$ & 173 & 271 & 178 & 161 & 137 \\
\hline $\begin{array}{l}\text { Foreign investments in } 1996 \\
\text { million USD }\end{array}$ & 14.6 & 1.3 & 1.7 & 145.3 & 143.6 \\
\hline $\begin{array}{l}\text { The number of joint ventures } \\
\text { and foreign companies, } 1996\end{array}$ & 63 & 140 & 165 & 1709 & 136 \\
\hline
\end{tabular}

habitants. This subregion is also the largest market for consumer goods in Northwestern Russia. Besides St. Petersburg and the surrounding Leningrad Oblast, only a few localities, principally Murmansk, Arkhangelsk and Petrozavodsk, possess a considerable number of inhabitants (Table 1), and thus a high aggregate purchasing power. In addition, Vologda and Syktyvkar have more than 200000 inhabitants. The northern military bases, including the naval and submarine ports of Severomorsk and Severodvinsk, have been considerable employers in the coastal area, and Russian troops stationed in the former Warsaw Pact countries have been relocated to the western parts of the region. Smaller urban areas are of significance due to either military or resource-based activities, and provincial companies and entrepreneurs typically trade in raw materials and semi-finished bulk products. The smaller villages continue to exist in isolated conditions (Varis 1996).

The purchasing power of an ordinary citizen in Russia was only 17.8 per cent of that in the USA and 23.7 per cent of that in Germany in 1994 and 16.6 per cent and 22.3 per cent respectively in 1995, and the distribution of income was as uneven as in Malaysia, Mexico, Nicaragua, the Dominican Republic or Colombia (World Bank 1996: 189, 196-197, 1997: 215). The workers in the Russian hinterland earn the highest wages, a legacy of the former Soviet income policy (Table 1). Commodities, no matter where they are produced, are available all over the region, but consumer demand has been low due to the delayed economic recovery. The low salaries and wages in Russia could be considered an advantage for Western investors, but this is substantially offset by low productivity and the expenses brought about by the poor infrastructure and operational risks. Nevertheless, Russia differs in many respects from typical developing countries. The provision of education is relatively abundant, for example, and pupils enroll in post-secondary schools and universities almost at the same rate as in many high-income economies (Radošević 1996: 187; World Bank 1997: 227).

Table 1 above shows that the focus of economic development potential is in St. Petersburg and Leningrad Oblast. This metropoli$\tan$ area is increasing in importance as a key Russian business hub and as a central node in the transport and communications infrastructure. The city is a dominant location for machine manufacturing, the munitions industry (now in a state of transition), the growing consumer goods sector and transport services. St. Petersburg's manufacturing sector has recovered since the deep decline between 1990-1994, and the recovery of this sector in St. Petersburg has been more rapid than in the other parts of Northwestern Russia, and in Moscow and the Russian Federation (Table 2). Residents have tended to vote for the reform parties (Clem \& Craumer 1995), a market economy and Yeltsin. Also, the city is culturally oriented towards the West owing to its short history (established in 1703) and gateway position. Foreign companies employed more than 40000 people in the city in 1995, 
Table 2. The index of industrial production 1992-1997 $100=1990$ and 1994 (Suomen Lähialueet 3/97).

\begin{tabular}{lcccccc}
\hline Region & \multicolumn{2}{l}{1992} & 1993 & 1994 & \multicolumn{2}{c}{1995} \\
& $1990=100$ & \multicolumn{4}{c}{$1994=100$} & 1997 \\
\hline Arkhangelsk Oblast & 85 & 80 & 63 & 92 & 87 & 90 \\
Murmansk Oblast & 83 & 72 & 63 & 97 & 97 & 100 \\
Karelian Republic & 79 & 69 & 55 & 103 & 84 & 92 \\
St. Petersburg & 82 & 73 & 47 & 87 & 79 & 115 \\
Leningrad Oblast & 88 & 78 & 59 & 105 & 93 & 100.2 \\
Russian Federation & 75 & 65 & 51 & 97 & 95 & 100.7 \\
\hline
\end{tabular}

and the total amount of foreign investment in 1995 was 150 million USD (Laurila 1996: 27), or 175 million USD if investments in the surrounding oblast are included (International Business Statistics 1996). Foreign investments increased considerably in the metropolitan area in 1997.

The crucial starting points for economic development in Northwestern Russia lie in the opportunities provided by St. Petersburg and in Northwestern Russia's abundant natural resources. The main geoeconomic characteristics of the region may be summarized by stating that Northwestern Russia is sparsely-populated and has only one populous metropolitan area which is culturally westernoriented. It has important transport links with the highly urbanized core areas of Russia, and its vast hinterland contains many resourcebased export industries and military and company towns.

\section{Innovative restructuring in its infancy}

Northwestern Russia is culturally and socially a heterogeneous region, which presents numerous social barriers and gateways that regulate innovation diffusion and channel the adoption of innovations at this early stage of transition. During the first years of capitalism, foreign companies were active in introducing business innovations (Johansen 1995), and Russian entrepreneurs and many public officials were openly eager to develop foreign contacts (e.g. Aalbu et al. 1995). In some enterprises, the growth in foreign trade and subcontracting made it possible to maintain or increase production, carry out new investments and import of investment goods. For instance, the successful operation of a Russian-German shipbuilding company in Petro- zavodsk is an example of this development, and a few similar examples can be found in Northwestern Russia. The development of market relationships and trading practices between foreign and Russian firms have been crucial for modernization because of two reasons: the revenues from sales have made it possible to invest and co-operation has had positive spin-off effects on the quality of production and production technology. Domestic demand has not yet recovered and developed at least in Karelia as to result in similar effects. This conclusion is derived from the interviews and visits to companies in Karelia.

Under the unsettled conditions prevailing in Russia, innovation transfer is based on the mobility of people who actively search for innovations. One immediate reason for this Russian trait is the poor communication infrastructure (Bater 1996: 289-290). Up to the latter half of the 1990s, the primary reasons for the sluggish adaptation of innovation and hence for innovative restructuring - have been economic, organizational and policy-related. Firstly, the modernization of industry is impeded by the dramatic decline of production and hence, the demand of modern technology is low. The real capital of the Russian industry ages rapidly. For instance, 61 per cent of the production equipment of industry were older than 10 years in 1995 compared with 29 per cent in 1970 (Sokolin 1997, 85). Secondly, the organizational reasons are derived from the administrative break-up of the networks of companies and R \& D organizations. For instance, the large volume production units such as pulp and paper mills in Karelia are independent companies which are not automatically served by research and development institutions as was the case under central planning. Russian R \& D is evidence of the continuing lack of coordination between science and production and hence, 
there is a need for new organizational structures which serve the innovation process (Loginov \& Kulagin 1995). Thirdly, the Russian economic system is still isolated from Western influences and technology, in part due to political reasons. Foreign direct investment (FDI) is a measure of this isolation. For instance, the cumulative stock of foreign direct investments for the period of 1990-1996 is estimated to be 50 USD per capita in Russia. For comparison, the per capita FDI stock is 1400 USD in Hungary, 700 USD in the Czech Republic and even in the Slovak Republic is 170 USD. The above data is based on the balance of payment statistics (Countries in Transition 1997: 395). Foreign direct investments per annum in the North (Murmansk Oblast, Karelian Republic, Arkhangelsk Oblast, Vologda Oblast and the Komi Republic) were only 6 USD per capita in 1996 whereas they were 21 USD in St. Petersburg, 26 USD in the Leningrad Oblast and 14 USD in the country as whole (Suomen Lähialueet 4/97: 14, 61). Production decline and the break-down of the former associations of production and R \& D relations are the immediate results of recent economic transformation and its management. The reasons for low foreign participation in modernization are a more complex issue.

When investigating in a more structural way, the obstacles to innovative behavior are in part similar to the barriers faced by technology transfer, as discussed in theory (e.g. Geenhuizen 1994: 255), but their concrete manifestations are unique. Barriers existing in the socio-economic environment require special attention in transitional countries, and the obstacles to innovative behavior should be analyzed in a broad, institutional setting. This broad setting is needed because transition, adhering to the principles of capitalism, restructures the cultural, institutional and organizational foundations of society, influencing the preconditions for innovative behavior and innovation diffusion.

Although Northwestern Russia has been in a state of turmoil and decline for several years and outdated factories still abound, the innovative behavior of the local people must not be underestimated. Two general observations related to innovative behavior need to be emphasized. The changes that have taken place in Russia have been both rapid and profound, and citizens have had to respond with innovative behavior in order to cope. Also, owing to the socio-spatial characteristics of Northwestern Russia, it is very probable, that the innovative restructuring and the adoption of innovations will occur unevenly.

\section{Erratic restructuring - 'Stunde Null'}

Since perestroika, Russia has become a more open society. In addition to democratization and privatization, the most evident of all the changes that have taken place - for ordinary people - has been the influx of foreign consumer goods since the early 1990s. The dissolution of the command economy between 1991 and 1992, opened up possibilities for small entrepreneurs from foreign countries to operate in Russia and to establish new, direct business contacts. Simultaneously, the Russians, as individuals and representatives of their companies, began to conduct business directly in foreign countries. This development process has taken place in an unstable business environment, however, and social costs have been high (e.g. Illarionov et al. 1994; Popova \& Tekoniemi 1996).

One cannot ignore the many bottlenecks in production, distribution and in the business environment. Foreign companies, especially smaller Nordic ones, still feel that penetration into the markets of Northwestern Russia is difficult (Hietanen et al. 1997; Svensson 1997). Some have experienced difficulties with the mafia, for instance (Finnmark Dagblad/ Norwegian Telegram Bureau 1996), and all are subject to the cumbersome bureaucracy and constantly changing rules of the Russian 'market economy'. Exports and imports, and other foreign transactions, are regulated in a complex and often short-sighted manner. Many negativities can be attributed to inexperience, nationalism, protectionism and inherited' structures.

The most fundamental hardship is a sharp decline in production, which has continued through every year of 1990s. This is even more serious for the resource-based region of Northwestern Russia since declining production has cut output and incomes and led to the stalling of many promising reconstruction projects. Consequently, many technological improvements in resource sectors such as gas, oil, minerals and forestry have been delayed.

Russia and the CIS countries are still struggling much more with the economic upheav- 
al compared to the East-Central European countries, where economic recovery began between 1993 and 1994 (Countries in Transition 1995: 328; Rautava 1995; Review of Economies in Transition 1995: 67). The Russian economy continued to decline in terms of GDP, agricultural production and industrial output between 1995 and 1996 (OMRI Daily Digest 1996; Review of Economies in Transition 1996: 83; Review of Economies in Transition 1997: 69), but at least the drastic decline of manufacturing output had ceased by the mid-1990s (Table 2). However, the Russian Federation does expect a relatively slow recovery and it is anticipated that the growth rate will reach $4-5 \%$ p.a. by the end of the decade (Yevstigneyev \& Voinov 1994: 5).

The years after the Gorbachev regime, which ended in 1991, have been called 'Stunde Null' (Tykkyläinen 1995: 9-10), an allegorical reference to the times following the collapse of the German state after the Second World War. The implication is that this is inevitably a time of disorder and economic chaos in which new institutions are gradually created and the reconstruction of society slowly quickens in pace. In the case of Germany, economic recovery took place over a long period and was strongly supported by funding from external sources, mainly from the USA through the Marshall Plan.

Despite the many similarities, developments in Russia differ from the Western European pattern. Official statistics indicate that funding of investment projects has been meager, at least in the hinterlands of Northwestern Russia (Table 1). The total stock of foreign direct investments in Russia was smaller than in Poland and much lower than in Hungary up until the mid-1990s (Bradshaw 1997: 82), and negligible per capita as shown earlier in this paper. It is no wonder that many top officials, including Chernomyrdin (1996) and Shlyamin (1995), are dissatisfied with such a low level of foreign investments which could modernize the Russian economy. On the other hand, the small amount of foreign investments is a result of protectionist economic policy carried out by federal and regional authorities, the officials themselves. Especially the low level of foreign direct investment in Karelia (less than 2 USD per capita in 1996) and Murmansk Oblast (less then 1 USD) indicates a contradiction amidst economic opening-up, strategic interests and the striving for control of natural resources.
In order to make investments less risky for foreign companies, the Karelian Republic established an industrial mortgage fund in 1997, the collateral of which being forest, land and buildings owned by the state (Kuzmin 1997). On the other hand, many authorities and ordinary people prefer a form of development that keeps the control of productive capital in the hands of national institutions and the Russians themselves (Interfax 1996). Some officials in Karelia consider that the social consequences of privatization have been severe and thus, the Republic's control of companies should be increased (Kuzmin 1997). Kuzmin (1997) would also like to see a decrease in the number of small export companies, whereupon the prices of natural resources could be better controlled by the Republic (Kuzmin 1997). This opinion represents the wider view of the overall control of trade. Many authorities in regional administrations are anxious to set quotas of goods to be supplied for barter and direct trade and to introduce rationing, which reduces incentives to respond to market signals. When put into effect, this process will effectively compartmentalize the Russian economy (Sutherland \& Hanson 1996: 378).

Nevertheless, people, authorities and enterprises in Karelia are very eager to increase cooperation with foreign companies and to develop communication links across the border (Kuzmin 1997). These attitudes became also clear when 72 students in the business schools of Sortavala and Petrozavodsk were solicited using questionnaires in February 1997 (Table 3). The small number of cases in the sample allow only (statistically) indicative results.

The students did not have a decided opinion that western business practices are superior but they realized that the former Soviet way of conducting business hinders development. Surprisingly, they did not blame the economic liberalization for social problems, but they were not very convinced of the positive results of privatization. In general, they were strongly for deeper integration and the increase of transport links. In practice, opinions were protectionist, as is the case in everyday business cooperation. Joint venture companies were considered vital, but students became uncertain when they took a stand on foreign investments. The Karelian business climate favors the market economy, integration and opening-up, in principle. How to 
Table 3. The economic environment in Karelia, the opinions of business school students $(n=72)$ in February 1997 (Tykkyläinen 1997). Eleven statements were presented in questionnaires to the students in Sortavala $(n=20)$ and Petrozavodsk $(n=52)$.

Western practices and the impact of the former system:

Business is successful only by adopting western practices

$28 \%$ 'difficult to say', $42 \%$ agreed (to any degree) and $30 \%$ disagreed (to any degree) with the statement. Overall, students were not very sure about the superiority of western business practices.

Socialist way of thinking is the greatest obstacle

$39 \%$ 'agree or slightly agree', $13 \%$ 'strongly agree', $28 \%$ 'difficult to say'. A narrow majority $(51 \%)$ of students thought that the socialist way is more or less an obstacle, but students were not very sure about it.

Transition and integration:

Privatization will increase everyone's living standard

$38 \%$ 'difficult to say', $24 \%$ 'slightly agree', $15 \%$ 'slightly disagree'. Generally, $76 \%$ had no strong opinion, and students were not sure about the direct effects of privatization on living standard.

Economic liberalization is the cause of social problems

$26 \%$ 'strongly disagree', $31 \%$ 'disagree', $10 \%$ 'slightly disagree'. Overall, $07 \%$ agreed (to any degree) that economic liberalization is not the cause of social problems.

The Karelian Republic should join the EU

$51 \%$ YES , $11 \%$ NO, $38 \%$ 'difficult to say'.

I do not welcome new road and railway links to Finland

$51 \%$ disagreed (to any degree), $30 \%$ 'difficult to say', $20 \%$ agreed (to any degree). Students would like to see the development of road and railway links from Karelia to the West.

Protectionism:

Only Russians should own Karelian business $27 \%$ 'strongly agree', $34 \%$ agree or slightly agree. Overall, $61 \%$ agreed (to any degree) with that Karelian businesses should own by Russian citizens.

The export of roundwood to Finland should be restricted $46 \%$ 'strongly agree', $34 \%$ 'agree or slightly agree'. Overall, $78 \%$ would like to see roundwood exports to Finland to be restricted.

Foreign business and investments:

Joint venture companies are very necessary for Karelia

$32 \%$ 'agree', $25 \%$ 'slightly agree', $22 \%$ 'strongly agree'. Overall, $78 \%$ agreed (to any degree) that joint venture companies are very necessary to Karelia.

Foreign investment is vital for Karelia's future economic growth

$33 \%$ 'difficult to say', $26 \%$ 'slightly agree', $17 \%$ 'agree', $11 \%$ 'strongly agree'. Students were uncertain about the vital importance of foreign investments, but $54 \%$ agreed (to any degree) with the statement.

I would like to see more foreign investments in Karelia

$39 \%$ 'difficult to say', $23 \%$ 'slightly agree'. Students had suspicious opinions about foreign investment, but $41 \%$ considered the increase of them positive and $20 \%$ negative.

proceed with foreign investments in Karelia is not very clear. The Karelian economy is faced with the dilemma of protectionism and the need for opening-up to the global economy and the adoption of advanced technology.

Apart from St. Petersburg, the authorities in Northwestern Russia have not yet succeeded in creating an environment which attracts major investments from the West. The restruc- turing of Russian industry can be labeled as erratic, and the economy as a whole does not yet function like a developed market economy. Northwestern Russia has been a risky, unstable region for domestic and foreign investors - at least during the first half of the current decade. The opening of the Northwestern Russian economy to foreign investments has been negligible considering the abundance of natural resources in the region. 


\section{Learning by doing and inherited structures}

Northwestern Russia was intensively developed according to the socialist principles during the Soviet Era. Companies in the vast hinterland supplied roundwood, forest industry products, ores, metals and metal products to other parts of the economy and directly to consumers. A proportion of their production was earmarked for foreign markets, but under the strict control of the economic planning authorities and the Soviet foreign trade organizations. Economic transactions were based on the rules of the command economy (i.e. on long-term plans and production targets within each branch of the economy). Independent operation was an unknown phenomenon for a Soviet company, and consequently, company managers and staff in peripheral areas had only very limited knowledge and access to market economy business techniques when the transition began. According to the interviews conducted in Northwestern Russia, people have adopted to a market economy by a 'learning by doing' method. The lack of any solid normative basis of the market economy helps to explain the spatial heterogeneity of the transition.

Economic recovery has already begun in the former CMEA countries, where economic liberalization has been much stronger than in Russia (World Bank 1996: 30). The transitional period in Russia can be expected to be much longer than in the small Eastern European countries. What might the reasons be for these differences? The historical legacy of the Soviet and czarist period provides one explanation. Entrepreneurs complain today of the bureaucratic and unstable conditions, and it seems that the long duration of economic turmoil is partly due to the cumbersome social practices and overregulation, which still prevail (Major 1994: 333-340), as well as to the lack of knowledge of the sophisticated principles of the market economy.

The concept of an inherited structure in transitional countries has been used in illustrating economic structure (Sutherland \& Hanson 1996) or the meaning of the entire communist heritage in society, physical environment and nature (Paul 1995). The authors interviewed enterprise leaders and authorities in Russia between 1993 and 1997, and the results revealed that three types of inherited socio-economic structures could be identified within Northwestern Russia which regulate the restructuring of industry. Institutional conditions, the underdeveloped service sector and the organization of enterprises are causing lags in transition. Unlike the situation in Russia, innovation-oriented development has long been part and parcel in companies operating within market economies and this pro-innovative outlook is imprinted on the everyday life and culture of citizens. The mental attitude for change is more positive with market economies and this alone is usually enough to give such countries an edge for development (e.g. Hisrich \& Ó Cinnéide 1992). In the former Soviet Union, this was not the case. The passage of information was not free, but was bound within an economic system that was guided and directed bureaucratically (Dyker 1994: 76-78), with all experiences of market economies being eliminated from the collective memory of society. Simultaneously, however, some knowledge of capitalism survived in the Eastern European countries (e.g. the Czech Republic, Hungary and Poland) and their institutions, despite the in-power communists. This legacy made the return towards a market economy easier. The institutional structures of the former Soviet Union, in the form of habits, customs, social rules, legislation, economic behavior and education, differed greatly from those of the market economy. From the questionnaire, the students' attitudes reveal that the mental climate in Russia does not favor a very open, international business environment. 'Stunde Null' can be expected to prevail for some time.

Institutional reforms and market-supporting institutions are urgently needed (World Bank 1996: 144-145) as there is a lack of organizational expertise on how to make use of innovative behavior for the long-term benefit of the entire society. In Russia, the system of producing and disseminating information and technological innovations to entrepreneurs and companies is poorly developed and technologically often outdated and market-led. practices have not become sufficiently institutionalized. Research institutions are in financial difficulties and companies await technological transfer and loans from abroad. Inherited service-sector structures, (i.e. the lack of a modern system for producing and disseminating innovations) tend to reinforce the barrier to development. This underdeveloped $R$ \& D and information service sector is obviously hindering the recovery of the Russian 
economy, since one of the preconditions for successful business management in a market economy is the availability of opportunities through which to acquire knowledge from the market, new technologies of production and new business methods.

Although the modern market economy is replacing other modes of production, Russian enterprises still possess the remains of their old organizational structures, including attitudes and behavior from the times of the command economy (Boycko et al. 1994; Chubais \& Vishnevskaya 1994; Varis 1996). For instance, a company owned (and may still own) shops and kindergartens and was usually the main provider of public utilities in industrial towns (Melin 1997). Furthermore, the organization of work has not changed significantly, even in the privatized companies, and the process of change in companies is slow. Many business managers are well aware of the inevitable changes, but the complex system of economic, institutional and social relations bind companies and allow for only slow progress. From an innovation diffusion point of view, these organizational structures, coupled with obsolete productive assets, pose significant obstacles to rapid recovery in Russia.

Barriers are inherited and embedded in Russian communities to varying degrees. Development in peripheral localities is further complicated by their remote location, where traditions have more of a stronghold. Overall, the transitional changes have not yet been able to eradicate the inherited barriers to innovation-oriented development.

\section{Russian solutions: endogenous elements}

Capitalism is an abstract model and the market economy develops differently in different institutional settings (Nielsen et al 1995: 17). Economic development in Russia is difficult to predict, as it does not follow the rules of the 'European' market economy. The fact that a market economy itself can be viewed as a social innovation in Russia complicates the outlining of future paths. Russians are developing their own endogenous nuances within the market economy.

Russian socio-economic restructuring does not follow exactly in the footsteps of any Western type of market economy. It is a mix- ture of laissez-faire (especially in small businesses), a market economy and old socialist practices (Tykkyläinen 1996). For instance, along with private investors and authorities, employees or their organizations have become co-owners of the privatized companies. This solution is typical in Russia but not very common in developed market economies, where ownership often rests with institutional investors and complex shareholder arrangements. Russia has developed endogenous solutions in the agricultural sector. For instance, some family farms have been founded, but company-based, large-scale farming is still practiced in southern parts of Northwestern Russia. Additionally, Russia does not follow the Nordic model of a welfare state, and companies and adjunct organizations continue providing many social services. The Russian adaptations within the framework of a market economy are distinctly original.

Privatization has been rapid, with 70 per cent of the employees working outside the public sector in the mid-1990s. Additionally, the informal private sector constituted approximately 20-25 per cent of GDP (Rautava 1996: 15, 11), and even as much as one-third according to some estimates (e.g. Klüter 1996: 30). Innovative behavior faces disintegrating social structures, the lack of advanced institutional structures to promote it and it must also cope with the 'infrastructure of former priorities'. The wealth gap among the various groups of society (people, enterprises and communities) is increasing. As an example of retaining the past regulative traditions, local authorities still wish to regulate inter-regional and foreign trade. The complex socio-economic fabric of Northwestern Russia is composed of very modern elements and old structures leading to a non-uniform socio-economic restructuring. Such a development is one symptom of institutional lags in the different parts of the socio-economic structures. Superficially, the shift to a privatized economy has been rapid, and one reason for this development is that employees have been allowed partnership arrangements and have thus accepted privatization. The transition towards a market economy is based on both the relocation of an abstract idea of market behavior, and on Russia's own models and experiments, resulting in varying geographical manifestations. The Russian transition model contains strong endogenous elements in its adaptation of market economy principles. 


\section{The European division of labor and Northwestern Russia: external pressure}

Northwestern Russia was assigned a resource region role in the socialist economic division of labor. This has led to a spatioeconomic structure in which most of the economic activity was geared towards activities that were beneficial for the overall former USSR. This former planning created many resource and military localities in the Murmansk and Arkhangelsk Oblasts, which are still of great strategic importance and under the direct influence of government in Moscow. The Karelian Republic does not have significantly more self-governance than the oblasts, and it remains tied to the federal power because of its financial dependency on the federal government.

The liberalization of trade, which began in the late 1980s (Aven 1994), has generally been completed and companies have conduced their foreign trade themselves since 1991 (Orlov 1997: 10). Those Northwestern Russian firms that trade with foreign companies are now flourishing, because foreign business generates quick incomes. This trade generates spin-off effects, such as road improvements or construction works carried out by foreign contractors for the benefit of entire communities. Specific road work projects (Eronen 1993; Karjalainen 1995) and school construction projects (Karjalainen 1996), paid for by timber companies, show how round- wood exports have directly benefited the provision of public utilities. One of the most recent examples is the financing of central-heating installations through the sale of timber in a small settlement near the Finnish-Russian border (Helsingin Sanomat 1997b). Liberalization has created a niche for local activity to improve infrastructure. In most cases, however, direct trade connections have not resulted in appreciable growth. There has been low export demand for Russian bulk products as they often fail to meet the high quality standards of the export markets.

The largest businesses in Northwestern Russia, outside of St. Petersburg, are involved with timber and minerals, as stated in Table 4 . This is also true of the Komi Republic and the Vologda Oblast. For example, the Northwestern Russian annual timber harvest during the Soviet period (without bark) was 85 million cubic meters, more than that of any single European country. Thus, there are plentiful opportunities for foreign woodprocessing industries to acquire their raw materials from the region.

Minerals occupy an important position in the economy of the Murmansk Oblast. The Barents Sea gas reserves are considerable, comparable in size with those of the North Sea and the Norwegian Sea, but marine gas reserves have been completely unexploited (Euroil 1993). The Arkhangelsk Oblast has both large forest resources and significant timber production, and large oil and gas reserves are located in the Timan-Pechora re-

Table 4. Resources and infrastructure. (The importance or quality of a resource is indicated as follows: $+=$ moderate, $++=$ high, $+++=$ very high, $-=$ no information or data) (St. Petersburg State Committee of State Statistics 1993, 1994, 1995; Statistics Finland 1993, 1994, 1995; Jumppanen \& Hyttinen 1995; Seppänen 1995).

\begin{tabular}{|c|c|c|c|c|}
\hline $\begin{array}{l}\text { Resources and } \\
\text { infrastructure }\end{array}$ & $\begin{array}{c}\text { Arkhangelsk } \\
\text { Oblast }\end{array}$ & $\begin{array}{c}\text { Murmansk } \\
\text { Oblast }\end{array}$ & $\begin{array}{l}\text { Karelian } \\
\text { Republic }\end{array}$ & $\begin{array}{c}\text { St. Petersburg \& } \\
\text { Leningrad reg. }\end{array}$ \\
\hline forest & +++ & + & +++ & - \\
\hline fish & ++ & +++ & + & - \\
\hline minerals and metals & +++ & +++ & ++ & - \\
\hline oil and gas & $++t$ & +++ & - & - \\
\hline main industry group & forest industry & metallurgy & forest industry & machinery \\
\hline $\begin{array}{l}\% \text { of total output }-93 \\
\% \text { of total output }-94\end{array}$ & $\begin{array}{l}42.3 \% \\
46.9 \%\end{array}$ & $\begin{array}{l}43.4 \% \\
55.3 \%\end{array}$ & $\begin{array}{l}34.0 \% \\
45.0 \%\end{array}$ & $\begin{array}{l}39.3 \% \\
37.0 \%\end{array}$ \\
\hline $\begin{array}{l}\text { infrastructure in } 1993 \\
\text { - telephone apparates / } 100 \mathrm{inh} \\
\text { - } \mathrm{km} \text { of public roads } \\
\text { - } \mathrm{km} \text { of railways }\end{array}$ & $\begin{array}{r}10.0 \\
6604 \\
1781\end{array}$ & $\begin{array}{r}12.0 \\
2429 \\
933\end{array}$ & $\begin{array}{r}14.0 \\
6652 \\
2145\end{array}$ & $\begin{array}{r}25.0 \\
9647 \\
3650\end{array}$ \\
\hline
\end{tabular}




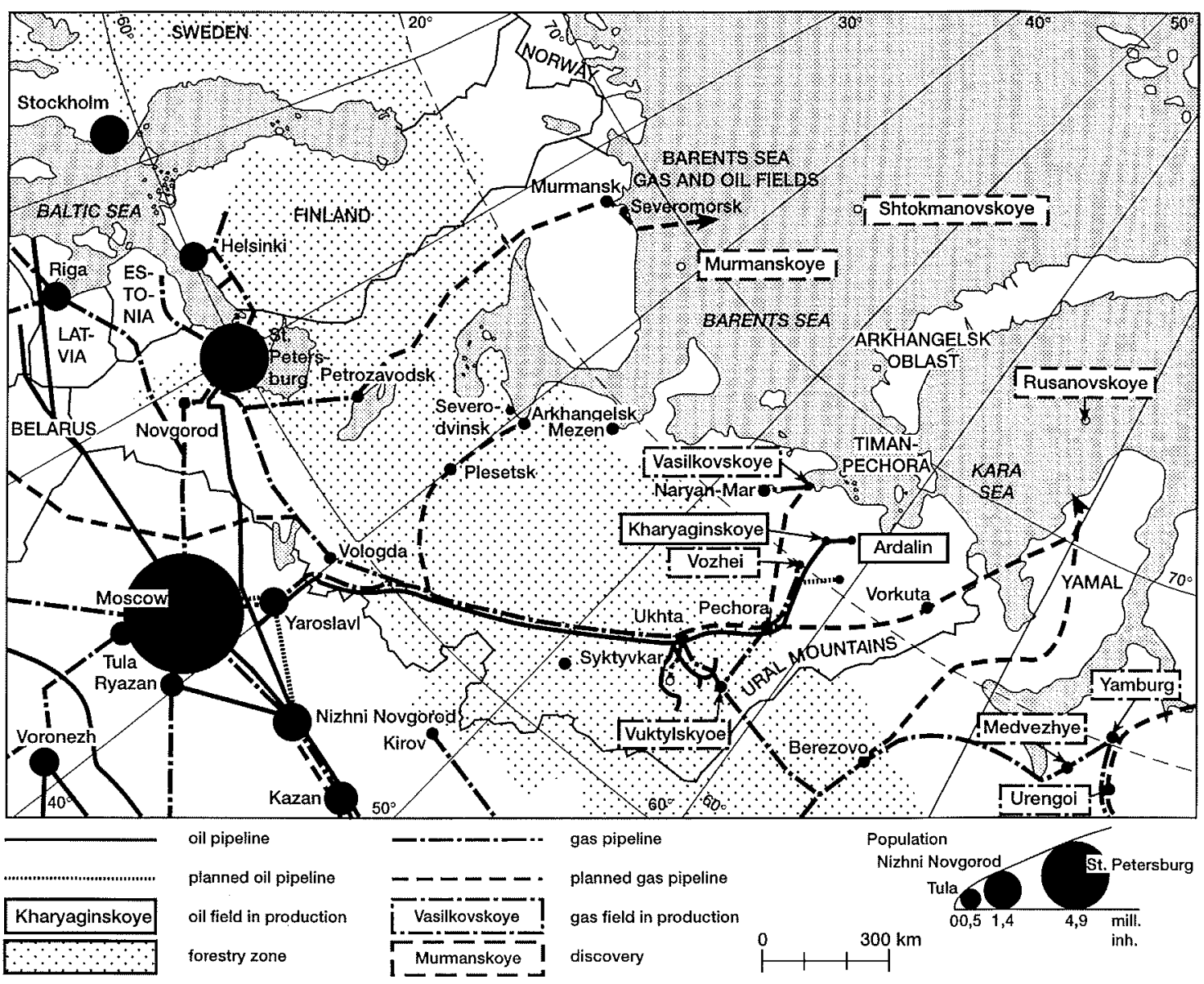

Fig. 2. Forests, certain hydrocarbon projects and major agglomerations in Northwestern Russia in 1997.

gion in the northeast. Many Western companies (e.g. Saga-Shell, Texaco, Neste, Total and Conoco) and some Russian companies are exploring these reserves (Fig. 2). The main Russian competitor is the hydrocarbon industry in Norway, which has succeeded in increasing production and will provide large quantities of gas for Europe during the coming decades.

Western Siberia (the fields of Urengoi, Yamburg etc.) accounts for the vast majority of Russian gas production. Gas and oil prospecting in the far north of Russia is actively pursued and the exploitation of reserves appears to be promising in the long run (Euroil 1995). There are plans for supplying gas from the Barents Sea to Europe. Further away, the hydrocarbon sector may modernize the Nenets Autonomous District, where considerable oil and gas reserves exist. By exploiting the fields of the Yamal gas projects, Gazprom (the largest Russian gas company) is convinced that it could supply the growing requirements for gas in Europe in the next century. Presently, Gazprom accounts for nearly half of all gas imports to Western Europe (Russian and Baltic Economies 1997).

Modernization continues slowly and only a few hydrocarbon reserves are being utilized. Progress has been slow in other resource sectors as well but the trade in forest resources, such as roundwood exports to Finland, is an important source of income for Northwestern Russia. There are, however, no pulp and paper mill greenfield projects in the entire region, and numerous examples from the Karelian Republic and the Leningrad Oblast attest to the fact that foreign companies have 
been wary in their attempts to penetrate the resource sector in Russia.

International business cooperation initiated with firm-to-firm contracts and has resulted in gradual modernization. A few examples will illustrate this:

- Low production costs in the Karelian furniture industry are being harnessed, as observed by the authors, at a company in Sortavala in 1993 and 1995. Nevertheless, this Karelian furniture company, simultaneously operating as a subcontractor and supplier for Swedish and Finnish customers, could not find foreign markets for its skis and parquet flooring due to quality deficiencies. Only parts of furniture and a few low-price pieces of furniture were attractive to clients in Western market. By early 1998, the company was bankrypt.

- A former Soviet shipyard in Petrozavodsk is now (1997) a Russian-German joint venture and it assembles ships from parts imported from Germany. The company is one of the few examples of successful joint ventures in the manufacturing sector in Karelia.

- A sawmill in Läskelä is owned by the Russian-Finnish joint venture company, Ladenso, and the shared ownership helps in finding foreign markets and organizing the market channels for sawn timber abroad. The company also supplies a considerable amount of roundwood to a large pulp mill (Enocell) in Finland, which was intended to be a Finnish-Soviet joint venture when it was established in the late 1980s. It is now owned and controlled by the Finnish partners due to financial difficulties on the part of the Russian partners.

- A large paper plant in Segezha has Assidomän, a Swedish paper company, as foreign partner. Assidomän owns 57 per cent of the shares of the plant and has plans to invest 100 million USD in modernizing the Segezhabumprom plant (OMRI Russian Regional Report 1996). Assidomän has encountered more problems in Segezha than expected, and as of December 1997, the company had a tax dispute with the federal authorities. The company was considering closing the plant in December (Dagens Industri 1997), and the decision of closure was made in January 1998 (Helsingin Sanomat 1998a).

- The Pitkäranta pulp mill was planning to modernize its outdated production facili- ties in collaboration with an Austrian com pany in 1995 (Rohlov 1995; Sokolova 1995). The Austrian partner was partly selected because the Pitkäranta pulp mill is competing with the Russian-Finnish joint venture, Ladenso, for wood in the same border region.

- The Swedish company, Tetra Pak, is modernizing the Svetogorsk paper mills in the northwestern corner of the Leningrad Oblast.

- Several agreements have been negotiated by Norilsk Nickel and Outokumpu (Finland) in the last few years to modernize mines and smelters. The Russian company has mines and smelters in Northwestern Russia and Siberia. Reconstruction has yet to begin in Murmansk Oblast or elsewhere, however.

- The shipyard at Vyborg, in the Leningrad Oblast, is in part owned by Kvaerner, a Norwegian company which also owns a large shipyard in Finland. The shipyard co-operates with the other shipyards of Kvaerner in producing ships, platforms and sea equipment for the international market and the shipyard is also the bridgehead for Kvaerner to the Russian market. Kvaerner is investing especially in the information technology of the Vyborg shipyard (Helsingin Sanomat 1996).

- In 1997, a preliminary agreement was reached by General Motors (Adam Opel), Valmet Automotive, Avtovaz and AVVA to establish a car assembly plant in the Karelian Republic or in Vyborg. The assembly of Opel cars was planned to commence in autumn 1998 (Helsingin Sanomat 1997a). The project progressed much slower than expected, and the future of the plan is uncertain (Helsingin Sanomat 1998b). According to Avtovaz, the Vyborg plant will most likely not be built and instead, an assembly plant might be constructed in Togliatti, on the Volga River. (Helsingin Sanomat 1998c). Regardless of these developments, Valmet Automotive continues to assemble Russian cars in Finland.

- The North West Regional Venture Fund (of the European Bank for Reconstruction and Development), principally financed by the governments of Finland, Norway and Sweden, aims at modernizing medium-sized companies. As of February 1997, NORUM the investment management company of the North West RVF, had put money into a 
sawmill and a greenhouse in the Arkhan gelsk Oblast and a hotel in the Murmansk Oblast, for a total investment amounting 3.4 million USD (Vistbacka 1997). Foreign investment ventures such as these are still in their infancy.

Companies in Northwestern Russia are thus gradually becoming linked to the sources of modern technology, but the price of this is usually the relinquishment of either some domestic control over the company or production to a foreign partner. Only a few Russian companies have been in a position to be able to purchase technology and new machinery.

The external pressure originates from two facts. First, the resource sector needs to be restructured according to the demand of broader markets and, second, foreign companies are interested in Russian trade as a part of their general business strategies. The role of Northwestern Russia in the European division of labor clearly is based on natural resources, but economic environments differ so much that integration has been slow. Many Russian companies have lagged behind for so long that the transfer of modern technology from foreign companies is the most feasible solution - and almost the only way to achieve this is to accept those foreign companies as partners. Innovations are arising from exogenous sources, and have to be simultaneously integrated into the broader, international market.

\section{The influence of infrastructure}

Improvements in infrastructure will facilitate the future development of Northwestern Russia. The large urban agglomeration, St. Petersburg, which in terms of population is larger than the metropolitan areas of Copenhagen, Stockholm and Helsinki combined, is updating its infrastructure. One can argue that such changes will have greater effects in terms of money flows, trade and contracts than any other development project in the near future. Despite the significant economic weight of St. Petersburg and the necessity of infrastructural investments in the city, the resourcebased hinterland will also require considerable infrastructural investments in order to be attractive for modern resource exploitation.

The primary infrastructure of Northwestern Russia consists of the railways and wa- terways, although road transport is gaining importance. Russia's safest and most reliable transport connections link its heartland with foreign countries through the northern seaports on the North Atlantic Ocean, the White Sea and the Baltic Sea.

Communications, in terms of both telecommunications and transportation infrastructure, call for investments (Tables 4 and 5). Arkhangelsk Oblast is almost as large as the whole of France and larger than Finland, and yet has only just over 6600 kilometers of public roads. The corresponding figure for Finland is some 88000 kilometers. The population of Arkhangelsk Oblast is one-third of that of Finland.

This same pattern repeats itself in telecommunications. The number of telephone apparates per 100 inhabitants is low (Table 4). According to Seppänen (1995), the actual telephone subscription figures were 1.9 per hundred persons in the Murmansk region and 2.4 in Karelia, whereas in the Nordic Countries the figures were 53 for Northern Norway, 70 for Norrbotten in Sweden and 50 for Lapland in Finland. Thus, even in the peripheries of the Nordic Countries, the number of telephones per capita is up to 20 times of that in Northwestern Russia.

The poor state of infrastructure takes on a more concrete form when one considers the everyday business environment (Table 5; Alanen 1997). These factors often form a tacit, hindering dimension working against innovative behavior, as people are so consumed by the hardships of everyday life that it distracts people's attention and interest in modernization.

Everyday life in Northwestern Russia is secular and is a mixture of several cultural traditions. Urban life in particular is multicultural, which is, in principle, conducive to economic transition. On the other hand, the indigenous cultures in the ultimate periphery may have difficulties in participating in future modernization. The difference in the standard of living between Russia and the West often hampers efforts at cooperation.

Modernization is continuing in everyday life despite the economic decline and severe social and infrastructural problems. People are adopting practices (such as private ownership) and changing their consumption patterns more rapidly than at any other time since the Second World War. The shortcomings of society are affecting people's liveli- 
Table 5. Characteristics of business and living conditions in Northwestern Russia, according to the interviews between 1993-1996.

\begin{tabular}{|c|c|}
\hline Type of service & Characteristics \\
\hline Provision of goods & $\begin{array}{l}\text { Food supply } \\
\text { - domestic and sometimes restricted by the scarcity of foodstuffs }\end{array}$ \\
\hline $\begin{array}{l}\text { Community } \\
\text { infrastructure }\end{array}$ & $\begin{array}{l}\text { Energy production } \\
\text { - cuts in supply due to technical failures and shortage of fuel } \\
\text { (mainly oil-based) } \\
\text { - factories supply heat to the adjacent communities (dependence) } \\
\text { Water supply } \\
\text { - tap water, if available, is not potable in many localities }\end{array}$ \\
\hline $\begin{array}{l}\text { Travel and } \\
\text { accommodation }\end{array}$ & $\begin{array}{l}\text { - hotels do not meet Western standards; modest accommodation in the } \\
\text { periphery } \\
\text { - telecommunication services are lacking } \\
\text { - few roads and lack of fuel, diesel is most commonly available } \\
\text { - changing customs regulations }\end{array}$ \\
\hline $\begin{array}{l}\text { Business services and } \\
\text { language }\end{array}$ & $\begin{array}{l}\text { - scarcity of business services } \\
\text { - poor knowledge of foreign languages } \\
\text { - difficulties in obtaining reliable information about business partners }\end{array}$ \\
\hline $\begin{array}{l}\text { Capital and banking } \\
\text { system }\end{array}$ & $\begin{array}{l}\text { - barter is common between companies as is insolvency, long delays in } \\
\text { payments, difficulties in making foreign payments } \\
\text { - inflation has been high and unpredictable }\end{array}$ \\
\hline
\end{tabular}

hoods and work (Table 5) and this is certainly making the adoption of rapid technological advances in the industrial sectors difficult. The local people feel that there are many issues of much greater importance to be solved than the introduction of sophisticated, laborsaving innovations.

It can be concluded that innovative restructuring is proceeding in a manner regulated. by specific factors generated from the Russian socio-economic circumstances and particularities. Business co-operation between Russian companies and foreign partners means the introduction of new ways of operating, not only in business but also in everyday life, as depicted in detail by Bond and Tykkyläinen (1996). Russian modernization is intertwined to the transformation of the entire culture. Business is modernizing Russia, however, it is essential for all foreign participants to take into account the specific circumstances of Russian culture and society.

\section{Toward theories of innovative restructuring and selective spatial modernization}

The lessons to be learned from the Northwestern Russian transition confirm that mod- ernization is an intentional and political process (involving various actors) with certain socio-economic regularities (such as seeking profit) and it is affected by the past social system (i.e. institutions, organizations and economic structures). The poor past performance of industrial plants and the former division of labor, based on non-market pricing, are inducing a profound and long-lasting restructuring of industry. Furthermore, modernization shows that the post-socialist economic systems have developed in an endogenous manner in the sense of being able to spawn a unique form of capitalism (cf. development in Poland and Hungary as depicted by Łoboda et al. 1998 and Süli-Zakar et al. 1998). Russia is developing its specific form of transition, currently consisting of a combination of laissez-faire, a more conventional market economy and modernized socialistic practices.

A theory of the innovative restructuring of industry, as the core of transition, is depicted and summarized in Figure 3. This conceptual framework illustrates the main causal forces regulating the modernization of Northwestern Russia. The empirical analysis of the Northwestern Russian economy revealed a contradictory development potential provided by the natural resources and the social 


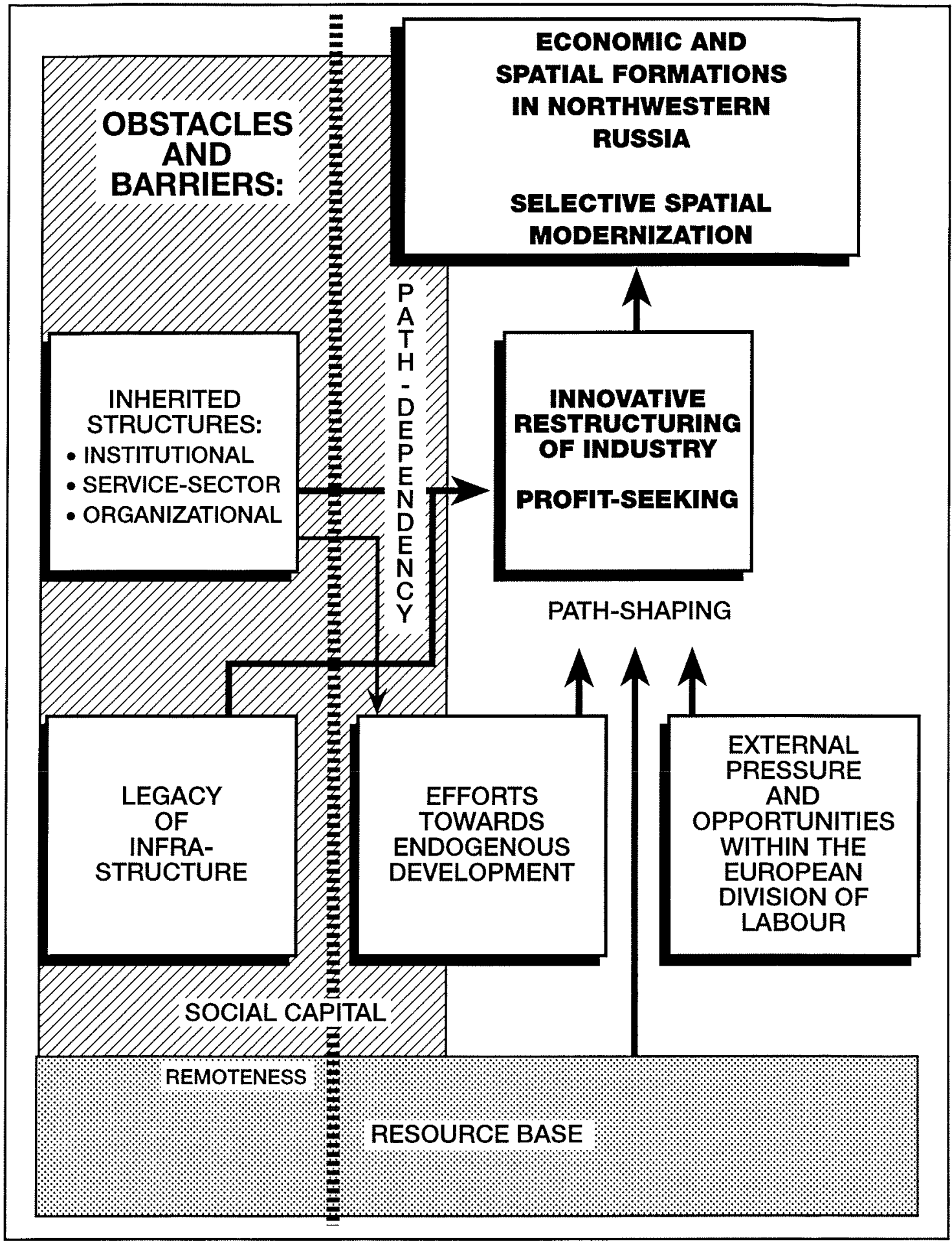

Fig. 3. Process of innovative restructuring of industry in Northwestern Russia leading to selective modernization. 
capital of Northwestern Russia. The region provides opportunities for investments because of its natural resource base, and it is obvious that the growth derived from the European and global markets will provide incentives for Northwestern Russian industrial modernization (Fig. 3). Obstacles and barriers (on the left side of the Figure 3) are the inherited structures and the legacy of infrastructure and remoteness. The obstacles to rapid innovative restructuring in Northwestern Russia, as viewed from the Western standpoints, are embedded in both the inherited socio-economic fabric of the region and current political (institution-shaping) choices. Endogenous, institution-shaping efforts are, at their best, enhancement of local social capital. However, often politicians attempt to develop semi-protected economies, and such efforts are supported by local entrepreneurs in order to safeguard their own interests. The operation of endogenous forces mean that a 'market' economy exists only within a certain political environment and this political factor may profoundly shape modernization and the formation of economic and spatial structures.

It can be summarized that there are two main forces of restructuring: path-dependen$c y$, in the sense of inherited structures and legacy, and path-forming processes, in the form of striving for new economic order. New spatial structures of industry are results of this struggle. The processes of restructuring are occurring quite differently within each company, location and community. Restructuring is a spatially uneven process, which will lead to the complete reforming of the former 'landscapes of priorities'.

If economic nationalism does not increase significantly and protectionism does lose its grip, the resource-based factories in Northwestern Russia will become parts of wider, international business networks. Innovative restructuring will increasingly take place in locations that are suitable for the global network, which include Northwestern Russia. Additionally, the nature of exploiting resources, long distances and harsh environments, together with the socio-economic variables described, will influence the future spatial pattern of modernization. Northwestern Russian localities can improve their competitive position best by abolishing socio-economic barriers and releasing the factors of production for global use. Capitalism selects locations on the grounds of profitability, and hence, innovative restructuring takes place in favorable pockets. Furthermore, many endogenous elements, such as the compartmentalization of the Russian economy and insiderled privatization, are a seedbed for uneven development. The pattern of uneven spatial development is discernible if one examines development in individual locales.

The spatially uneven development of the early 1990s implies that the modernization of Northwestern Russia will proceed as innovative business diffuses from one place to another, even over long distances, creating spinoff effects in the environs of the production sites. Development pockets are the adapters and developers of innovations. Technological innovations diffuse to industrial projects located in favorable environments where they can further benefit the business endeavor and produce higher returns. Viewed from a geographical angle, this process of restructuring can be called selective spatial modemization.

\section{Conclusions}

The Northwestern Russian case study infers that spatial restructuring, both innovative and non-innovative, takes place at the level of individual factories, communities and people. In this context, regional as well as local development is very often misinterpreted by exaggerating generalizations in the geographical space. Many regional theories dwell too much on the concept of an administrative region as a subject of development and do not sufficiently consider the enterprises and individuals, the actual actors of development. The theories of innovative restructuring of industry and selective spatial modernization attempt to avoid this trap, emphasizing instead the actors of development in geographical space. Ideal innovative restructuring is an interplay between individuals and organizations discovering new ways to conduct profitable business and to exploit opportunities provided by the attributes of certain places, communities and localities. In Northwestern Russia there is a long road ahead before such ideal innovative processes are reached.

This paper concludes with a policy recommendation that the role of the authorities should be that of creating market-supporting institutions and non-bureaucratic and innovative environments and enhancing social 
capital. The authorities can no longer be the primary actors determining the economic landscape of Northwestern Russia, if an efficient operation of a market economy is expected to develop in Russia.

\section{ACKNOWLEDGEMENTS}

Dr. Örjan Sjöberg gave valuable comments during the final stages of writing the study, and Mr. Kerkko Hakulinen, Lic. Phil., helped to find a wellgrounded solution to transcribe Russian names. Such academic endeavors are very appreciated by the authors. Interviews in Karelia in 1997 were funded by the European Commission under contract ERBFMMACT960147 as well as by Nordplus. The financial support of the Academy of Finland is also highly appreciated.

\section{REFERENCES}

Aalbu, Hallgeir, Even Høydahl, Heikki Jussila \& Ulf Wiberg (1995). A velge sina naboer. Barentsregionen som utenrikspolitisk og regionalpolitisk prosjekt. NordREFO 1995:4.

Alanen, Aku (1997). Minne uskaltaa investoida Venäjällä? Suomen Lähialueet 4/97, 50-53. Statistics Finland. Helsinki.

Amin, Ash \& Hausner, Jerzy (1997). Interactive governance and social complexity. In Amin, Ash \& Jerzy Hausner (eds.): Beyond Market and Hierarchy, 1-31. Edward Elgar, Cheltenham.

Aven, Petr (1994). Problems in Foreign Trade Regulation in the Russian Economic Reform. In Asslund, Anders (ed.): Economic Transformation in Russia, 80-93. Pinter, London.

Aydalot, P. \& D. Keeble (eds.) (1989). High technology industry and innovative environments - The European experience. 241 pp. GREMI, Routledge, London.

Bater, James H. (1996). Russia and the Post-Soviet Scene. Arnold, London.

Bellandi, Marco (1997). Localised productive knowledge and industrial districts as learning region. Paper presented at the 37th European Congress of Regional Science Association, 2629 August, Rome.

Bond, Derek \& Markku Tykkyläinen (1996). Northwestern Russia: a case study in 'pocket' development. European Business Review 96:5, 55-61.

Boycko, Maxim, Andrei Shleifer \& Robert W. Vishny (1994). The Progress of Russian Privatization. In Åslund, Anders (ed.): Economic Trantsformation in Russia, 101-110. Pinter, London.

Bradshaw, Michael J. (1995). The Russian North in Transition: General Introduction. Post-Soviet Geography 36:4, 195-203.
Bradshaw, Michael J. (1997). The Geography of Foreign Investment in Russia, 1993-1995. Tijdschrift voor Economische en Sociale Geografie $88(1), 77-84$.

Castells, Manuel (1992). Four Asian Tigers With a Dragon Head, A Comparative Analysis of the State, Economy, and Society in the Asian Pacific Rim. In Richard P. Appelbaum \& Jeffrey Henderson (eds.): States and Development in the Asian Pacific Rim, 33-70. Sage, Newbury Park.

Chernomyrdin (1996). News Cut: Chernomyrdin urges the Swedes to construct new Kola nuclear complex. A message from Itar-Tass on 2 May, submitted by Inge Nilssen to Barents-l, 5 May 1996.

Chubais, Anatoly B. \& Maria D. Vishnevskaya (1994). Privatization in Russia: An Overview. In Åslund, Anders (ed.): Economic Transformation in Russia, 94-100. Pinter, London.

Clem, Ralph S. \& Peter R. Craumer (1995). The Geography of the Russian 1995 Parliamentary Election: Continuity, Change, and Correlates. Post-Soviet Geography 36(10), 587-616.

Cloke, Paul, Chris Philo \& David Sadler (1991). Approaching Human Geography. 240 pp. Paul Chapman Publishing Ltd, London.

Countries in Transition 1995 (1995). WIIW Handbook of Statistics. $339 \mathrm{pp}$. The Vienna Institute of Comparative Economic Studies. Vienna.

Countries in Transition 1997 (1997). WIIW Handbook of Statistics. $437 \mathrm{pp}$. The Vienna Institute of Comparative Economic Studies. Vienna.

Dagens Industri (1997). Assidomän overväger lämna ryskt pappersbruk. 18 December 1997.

van Doren, Pascale (1995). Adopting the innovative environment approach. In Demazière, Christopher \& Patricia Wilson (eds.): Local Economic Development in Europe and Americas, 92111. Mansell, London.

Dyker, David A. (1994). Technology Policy and the Productivity Crisis in Eastern Europe, Economic Systents 18(2): 71-85.

Eronen, Jarmo (1993). Venäläinen ja suomalainen periferia: Permin Komin ja Kainuun aluetaloudellista vertailua. Review of Economies in Transition 1993:9, 19-46. Unit of Eastern European Economies, Bank of Finland, Helsinki.

Euroil (1993). Norway's key Role. November Issue.

Euroil (1995). Gazprom - the friendly giant. March Issue.

Finnmark Dagblad/Norwegian Telegram Bureau (1996). Norwegian firm co-operate with Russian Mafia. A message submitted to Barents-l by Lars Krogh, 16 July 1996.

Gartiser-Schneider, Nathalie (1997). The innovative process: An organisational process leading to different types of configurations, A regional approach. Paper presented at the 37th European Congress of Regional Science Association, 26-29 August, Rome.

van Geenhuizen, M. (1994). Barriers to technology transfer: The role of intermediary organizations. 
In Cuadrado-Roura, Juan J., Peter Nijkamp \& Pere Salva (eds.): Moving Frontiers: Economic Restructuring, Regional Development and Emerging Networks, 247-278. Avebury, Aldershot.

Giddens, Anthony (1984). The constitution of society: outline of the theory of structuration. $402 \mathrm{pp}$. Polity, Cambridge.

Grabher, Gernot \& David Stark (eds.) (1997). Restructuring Networks in Post-Socialism, Legacies, Linkages, and Localities. Oxford University Press, Oxford.

Hausner, Jerzy, Bob Jessop \& Klaus Nielsen (eds.) (1995). Strategic Choice and Path-Dependency in Post-Socialism, Institutional Dynamics in the Transformation Process. Edward Eİgar, Cheltenham.

Haug, P. (1991). The location decisions and operations of high technology organizations in Washington State. Regional Studies 25:6, 525-541.

Helsingin Sanomat (1996). Viipurin telakka selvisi neuvostoajasta vähin vammoin. 24 May 1996.

Helsingin Sanomat (1997a). Itärajan Opel-tehtaan rakentaminen alkaa tänä vuonna. 23 January 1997.

Helsingin Sanomat (1997b). Puukauppa käynnistyi 67 vuoden tauon jälkeen Kivipuron rajanylityspaikalla. 12 November 1997.

Helsingin Sanomat (1998a). AssiDomän sulkee Karjalan säkkitehtaan. 6 January 1998

Helsingin Sanomat (1998b). Sopimus Viipurin autotehtaasta lykkääntyy. 8 January 1998.

Helsingin Sanomat (1998c). Viipurin autotehdashanke kuivui kokoon. 24 January 1998.

Hietanen, Hanna, Maarit Kainuharju \& Elli Rissanen (1997). Kainuulaisten idänkauppa. REDEC Kajaani 3.

Hisrich, Robert D. \& Barra Ó Cinnéide (1992). Research Trends in Entrepreneurship: The Potential in Expanding Europe and transAtlantic Perspectives. Proceedings 7 th Nordic Conference on Small Business, 633-644. Turku School of Economics and Business Administration, Turku.

Illarionov, Andrei, Richard Layard \& Peter Orszag (1994). The Conditions of Life. In Aslund, Anders (ed.): Econonic Transformation in Russia, 127-156. Pinter, London

International Business Statistics 1996. Statistics Finland. Helsinki.

Interfax (1996). Russian Duma approves draft resolution on Norilsk Nickel, 16 February 1996. A message submitted to Barents-l by Inge Nilsen, 22 February 1996.

Johansen, Harley E. (1994). Locating Western-style retail outlets in the former Soviet Baltic Rim: The case of Neste Oy of Finland. In Tykkyläinen, Markku (ed.): Local and Regional Development During the 1990s Transition in Eastern Europe, 47-64. Avebury, Aldershot.

Jumppanen, Pauli \& Helena Hyttinen (1995). The Econonic Geography of the Russian Side of the Barents Region. 181 pp. The Finnish Barents Group. Helsinki.

Jussila, Heikki \& Markku Tykkyläinen (1996). Op- portunities and obstacles for innovative restructuring of industry in north-western parts of Russia. A paper presented at the 27th Annual Conference of the Regional Science Association International, British \& Irish Section, Edinburgh, 23-25 September 1996.

Karjalainen (1995). Tietyö Lentieraan edennyt ongelmitta. 29 November 1995.

Karjalainen (1996). Euroopan kuuluisin kyläkoulu. 2 November 1996

Klüter, Helmut (1996). Russland - Faktor der Entwicklung im Osten. In Heinritz, G., G. Sandner \& R. Wiessner (eds.), Der Weg der deutschen Geographie. Rïckblick und Ausblick. 50. Deutscher Geographientag, Potsdam 1995, Band 4, 26-52. Franz Steiner Verlag, Stuttgart.

Korhonen, Pekka (1994). Economism as a Pacific Peace Project, Philippine Political Science Joumal nos. 37 and 38 (1993-4), 1-28.

Kosonen, Riitta (1996). Boundary, Institutions, and Indigenous Development. Helsinki School of Economics and Business Administration B-161.

Kosonen, Riitta (1997). From patient to active agent: an institutional analysis of the Russian border town of Vyborg. In Amin, Ash \& Jerzy Hausner (eds.): Beyond Market and Hierarchy, 233-260. Edward Elgar, Cheltenham.

Kuzmin, Andrei (1997). Deputy Minister of Foreign Affairs, Karelian Republic, Personal communication. 19.2.1997.

Laurila, Juhani (1996). Katsaus lähialueisiin. Reviezv of Economics in Transition 1996:2, 17-44. Unit of Eastern European Economies, Bank of Finland, Helsinki.

Linz, Susan J. (1992). Innovation Strategies in Centrally Planned and Transition Economies. In Scanlan, James P. (ed.): Technology, Culture and Development, The Experience of the Soviet Model, 63-94. M.E. Sharpe, New York.

Łoboda, Jan, Zbigniew Rog \& Markku Tykkyläinen (1998). Market forces and community development in rural Poland. In Neil, Cecily \& Markku Tykkyläinen (eds.): Multicatisal Theory of Local Economic Development. United Nations University Press, Tokyo (in press)

Loginov, V. \& A. Kulagin, A. (1995). Measures to Activate Innovation Policy. Problems of Economic Transition 38(3), 78-89.

Major, Iván (1994). The Decay of the Command Economies. Eastern European Politics and Societies 8(2): 317-357.

Malmberg, Anders, Örjan Sölvell \& Ivo Zander (1996). Spatial clustering, local accumulation of knowledge and firm competitiveness. Geografiska Annaler, 78B(2), 85-97.

Marianovski, V. (1997). The Russian Economic Mentality. Problems of Economic Transition 39(9), $73-75$.

Melin, Harri (1997). Yritysten sosiaalipoliittinen rooli entisessä Neuvostoliitossa ja nyky-Venäjällä. Suomen Lähialueet 4/97, 23-25. Statistics Finland. Helsinki. 
Nielsen, Klaus, Bob Jessop \& Jerzy Hausner (1995) Institutional Change in Post-Socialism. In Hausner, Jerzy, Bob Jessop \& Klaus Nielsen (eds.) (1995): Strategic Choice and Path-Dependency in Post-Socialism, Institutional Dynamics in the Transformation Process, 3-44. Edward Elgar, Cheltenham.

Nijkamp, P., G. van Oirshot \& A. Oosterman (1994). Knowledge networks, science parks and regional development: An international comparative analysis of critical success factors. In Cuadrado-Roura, Juan R., Peter Nijkamp \& Pere Salva (eds.): Moving Frontiers: Economic Restructuring, Regional Development and Emerging Networks, 247-276. Avebury, Aldershot.

Nove, Alec (1996). Economics of Transition: Some Gaps and Illusions. In Knell, Mark (ed.): Economics of Transition, Structural Adjustment and Growth Prospects in Eastern Europe, 49-69. Edward Elgar, Cheltenham.

Offe, Claus (1995). Designing Institutions for East European Transition. In Hausner, Jerzy, Bob Jessop \& Klaus Nielsen (eds.) (1995): Strategic Choice and Path-Dependency in Post-Socialism, Institutional Dynamics in the Transformation Process, 47-83. Edward Elgar, Cheltenham.

OMRI Daily Digest (1996). Economic decline continues, No. 201, 16 October 1996, submitted by Natalia Gurushina to Barents-l, 17 October 1996.

OMRI Russian Regional Report (1996). A \$100 million investment project for Kareliya, Part II No. 6, 2 October 1996, submitted by Natalia Gurushina to Barents-l, 3 October 1996

Orlov, Vladimir (1997). Oikeudellisia ongelmia suomalaisten ja venäläisten yritysten välisissä sopimuksissa. Suomen Lähialueet 4/97, 8-12. Statistics Finland. Helsinki.

Paul, Leo (1995). Regional Development in Central and Eastern Europe: The Role of Inherited Structures, External Forces and Local Initiatives. European Spatial Research and Policy 2(2), 19-41.

Popova, Tatiana \& Merja Tekoniemi (1996). Social Consequences of Economic Reform in Russia. Review of Economics in Transition 1996:5, 27-52. Unit of Eastern European Economies, Bank of Finland, Helsinki.

Pozdniakov, A. \& V. Kurnyshev (1995). The Socioeconomic Situation of the Russian North and Measures for its Stabilization. Problems of Economic Transition 37(11), 46-66.

Radošević, Slavo (1996). Prospects of Building Science and Technology Capabilities in Central and Eastern Europe. In Knell, Mark (ed.): Economics of Transition, Structural Adjustment and Growth Prospects in Eastern Europe, 185-209. Edward Elgar, Cheltenham.

Rakitov, A. I. (1993). Civilization, Culture, Technology, and the Market. Problems of Economic Transition 35(11), 6-27.

Rautava, Jouko (1995). Venäjän järjestelmämuutos ja talouskehitys. Review of Economics in Transition 1995:1, 5-23. Unit of Eastern European
Economies, Bank of Finland, Helsinki

Rautava, Jouko (1996). Venäjän järjestelmämuutos ja talouskehitys vuonna 1995, Review of Economies in Transition 1996:2, 5-16. Unit of Eastern European Economies, Bank of Finland, Helsinki.

Review of Economies in Transition (1995). 1995:1. Unit of Eastern European Economies, Bank of Finland, Helsinki.

Review of Economies in Transition (1996). 1996:2. Unit of Eastern European Economies, Bank of Finland, Helsinki.

Review of Economies in Transition (1997). 1997:5. Unit of Eastern European Economies, Bank of Finland, Helsinki.

Rohlov, Leonid (1995). Chief Engineer, Pitkäranta pulp and paper mill. Personal communication 15.2.1995

Russian and Baltic Economies (1997). The Week in Review 45. Unit of Eastern European Economies, Bank of Finland, Helsinki.

Seppänen, Susanna (1995). The Barents Region: An emerging market. International Business Statistics, Statistics Finland.

Shaw, Denis J. B. (1995). The post-Soviet republics: Environmental and human heritage. In Shaw, Denis J. B. (ed.): Post-Soviet Geography, A Systematic Geography, 1-22. Longman, Harlow.

Shlyamin, Valerij (1995). Minister of Foreign Affairs, Karelian Republic, Personal communication. 12.11.1995.

Sjöberg, Orjan (1997). Shortage, priority and urban growth: towards a theory of urbanization under central planning. Paper presented at the session Östeuropas geografi, Geografdagarna, Uppsala, 25-26 April 1997.

Smilor, R.W., G. Kozmentsky \& D.V. Gibson (1988) Technology and Economic Development in the Modern Technopolis. Technology in Society 10, 435-445.

Sokolin, V. (1997). Shifts of Productive Capital Stocks in the National Economy. Problems of Economic Transition 40(4), 80-95.

Sokolova, Ella (1995). Chief Engineer, Pitkäranta pulp and paper mill. Personal communication 15.2.1995.

St. Petersburg State Committee of State Statistics \& Statistics Finland (1994). St. Petersburg in Figures -93 . Statistics Finland. Helsinki.

St. Petersburg State Committee of State Statistics \& Statistics Finland (1995). St. Petersburg in Figures -95 . Statistics Finland. Helsinki.

St. Petersburg State Committee of State Statistics \& Statistics Finland (1995). The Leningrad Region in Figures -95. Statistics Finland. Helsinki.

Süli-Zakar, István, Attila Sántha, Markku Tykkyläinen \& Cecily Neil (1998). Coping with socialist restructuring and the transition to a market economy in rural Hungary. In Neil, Cecily \& Markku Tykkyläinen (eds.): Multicausal Theory of Local Economic Development. United Nations University Press, Tokyo (in press). 
Suomen Lähialueet 3/97. Statistics Finland. Helsinki. Suonen Lähialueet 4/97. Statistics Finland. Helsinki. Sutherland, Douglas \& Philip Hanson (1996). Structural Changes in the Economies of Russia's Regions. Europe-Asia Studies 48(3), 367-392.

Svensson, Bo (1997). Managing Cultural Friction, Swedish Firms in Northwestern Russia. In Dellenbrant, J.-A. \& U. Wiberg (eds.): Euro-Arctic Curtains, 103-128. Cerum, Umeå.

Thrift, Nigel (1983). On determination of social action in space and time. Environment and Plantning D: Society and Space 1(1), 23-57.

Tykkyläinen, Markku (1995). 'Stunde Null' and Introduction to the course. In Tykkyläinen Markku (ed.): Russian Karelia - an Opportunity for the West the Pocket Theory of Development in the Socioeconomic Transition in Russia, 9-22. University of Joensuu, Human Geography and Planning, Occasional Papers 29.

Tykkyläinen, Markku (1996). Northwestern Russia at the crossroads - How does the European division of labour reach Russia. In Varis, Eira \& Sisko Porter (eds.): Karelia and St. Petersburg, From Lakeland Interior to European Metropolis, 169-190. Joensuu University Press, Joensuu.

Tykkyläinen, Markku (1997). Questionnaires. Author's files. Joensuu.

Tykkyläinen, Markku \& Heikki Jussila (1997). Potentials for innovative restructuring of industry in North-western Russia. A paper submitted to the TMR-course "Regional Development in North-eastern Edge of the EU", at the University of Joensuu, Mekrijärvi Research Station, Finland, on 17-28 February 1997.
Varis, Eira (1996). The Restructuring of Peripheral Villages in Northwestern Russia. Research for Action. 37 pp. UNU/WIDER, Helsinki.

Vistbacka, Allan (1997). CEO, NORUM Petrozavodsk Office, Personal communication. 21.2. 1997.

Wẹcławowicz, Grzegorsz (1996). Contemporary Poland, Space and Society. UCL Press, London.

Wilhelm, Beate (1997). Technology and Incubation Centres (TICs) - a living legend or current centres of competence? Paper presented at the 37th European Congress of Regional Science Association, 26-29 August, Rome.

World Bank (1996). From Plan to Market, World Development Report 1996. 211 pp. Oxford University Press, New York.

World Bank (1997). The State in a Changing World, World Development Report 1997. 265 pp. Oxford University Press, New York.

Wyman, Matthew (1997). Public Opinion in Postcommunist Russia. Macmillan, Basingstoke.

Yeung, Wai-chung Henry (1997). Critical realism and realist research in human geography: a method or a philosophy in search of a method? Progress in Human Geography 21(1), 51-74.

Yevstigneyev, Ruben, N. Arkady \& M. Voinov (1994). Economic Reform and Its Interpretations in Russia. 43 pp. Research for Action, UNU/ WIDER, Helsinki.

van Zon, Hans (1996). The Future of Industry in Central and Eastern Europe. Avebury, Aldershot. 